\section{Creeping Bentgrass Growth Response to Elevated Soil Carbon Dioxide}

\author{
B. Todd Bunnell ${ }^{1}$, Lambert B. McCarty ${ }^{2}$, Roy B. Dodd ${ }^{3}$, and Hoke S. Hill ${ }^{4}$ \\ Clemson University, Clemson, SC 29634-0375
}

James J. Camberato 5

Clemson University, Florence, SC 29506

Additional index words. creeping bentgrass, Agrostis palustris, oxygen diffusion rate, golf greens, soil gases, root growth, turf quality, carbon dioxide, oxygen

\begin{abstract}
Increased soil moisture and temperature along with increased soil microbial and root activity during summer months elevate soil $\mathrm{CO}_{2}$ levels. Although previous research has demonstrated negative effects of high soil $\mathrm{CO}_{2}$ on growth of some plants, little is known concerning the impact high $\mathrm{CO}_{2}$ levels on creeping bentgrass (Agrostis palustris Huds.). The objective of this study was to investigate effects of varying levels of $\mathrm{CO}_{2}$ on the growth of creeping bentgrass. Growth cells were constructed to U.S. Golf Association (USGA) greens specification and creeping bentgrass was grown in the greenhouse. Three different levels of $\mathrm{CO}_{2}(2.5 \%, 5.0 \%$, and $10.0 \%)$ were injected (for 1 minute every 2 hours) into the growth cells at a rate of $550 \mathrm{~cm}^{3} \cdot \mathrm{min}^{-1}$. An untreated check, which did not have a gas mixture injected, maintained a $\mathrm{CO}_{2}$ concentration $<1 \%$. Gas injection occurred for 20 days to represent a run. Two runs were performed during the summer of 1999 on different growth cells. Visual turf quality ratings, encompassing turf color, health, density, and uniformity, were evaluated every 4 days on a 1-9 scale, with 9 = best turf and $<7$ being unacceptable. Soil cores were taken at the end of each run. Roots were separated from soil to measure root depth and mass. Turf quality was reduced to unacceptable levels with $10 \% \mathrm{CO}_{2}$, but was unaffected at lower levels over the 20 -day treatment period. Soil $\mathrm{CO}_{2} \geq 2.5 \%$ reduced root mass and depth by $40 \%$ and $10 \%$, respectively.
\end{abstract}

The transition zone is the area found in the eastern and central United States where both cool $\left(\mathrm{C}_{3}\right)$ and warm $\left(\mathrm{C}_{4}\right)$ season turfgrasses can be grown, but neither is well adapted to the climate. Hot, humid summers make growing cool season turfgrass species, particularly creeping bentgrass, challenging (Christians, 1998). Creeping bentgrass is physiologically adapted to summertime air temperatures of 16 to $24{ }^{\circ} \mathrm{C}$ (Beard, 1997). Yet, temperatures in the transition zone often exceed $30^{\circ} \mathrm{C}$, resulting in stressful growing conditions.

Summer bentgrass decline is an all-inclusive term describing the deterioration of bentgrass quality during summer months. Several environmental and plant physiological factors are involved with summer bentgrass decline. Factors include compac-

Received for publication 24 Oct. 2000. Accepted for publication 4 June 2001. Journal paper no. 4633, South Carolina Experimental Research Station. Research conducted at Clemson Univ., Clemson, S.C. Use of trade names does not imply endorsement of the products named nor criticism of similar ones not named.

${ }^{1}$ Graduate Assistant, Dept. of Horticulture. E-mail: btbunne@clemson.edu

2Professor, Dept. of Horticulture. E-mail: bmccrty@ clemson.edu

${ }^{3}$ Professor, Dept. of Agriculture and Biological Engineering. E-mail: rdodd@clemson.edu

${ }^{4}$ Professor, Dept. of Experimental Statistics. E-mail: hhill@clemson.edu

${ }^{5}$ Associate Professor, Dept. of Crop and Soil Environmental Science. E-mail: jcmbrt@ clemson.edu tion from foot traffic and high temperatures and humidity causing heat stress, increased disease incidence, and excessive soil moisture levels. These can combine to create an overlooked problem, poor soil oxygenation and increased levels of soil $\mathrm{CO}_{2}$.

Gases make up $\approx 20 \%$ to $30 \%$ of a typical soil volume (Brady, 1984, Hillel, 1980). The soil atmosphere is defined as "the gaseous phase of the soil, being that volume not occupied by solid or liquid" (Bremner and Blackmer, 1982). Generally, the composition of soil air is similar to that of the atmosphere with two major exceptions, $\mathrm{O}_{2}$, and $\mathrm{CO}_{2}$. Oxygen and $\mathrm{CO}_{2}$ fluctuate in the soil, with an increase in $\mathrm{CO}_{2}$ relating to a decrease in $\mathrm{O}_{2}$ (Williamson, 1964; Hillel, 1980; Bremner and Blackmer, 1982).

Root cells respire, thus using $\mathrm{O}_{2}$ and releasing $\mathrm{CO}_{2}$. Oxygen is required by roots for growth and water and nutrient uptake (Williamson, 1964). Plants grown in soils with low soil $\mathrm{O}_{2}$ concentrations will experience a loss of turgor pressure and increased wilting (Letey et. al., 1961).

Turfgrass species have a relatively high tolerance to low soil $\mathrm{O}_{2}$ availability (Williamson, 1968). Oxygen availability in the soil is determined by the oxygen diffusion rate (ODR) which measures the amount of soil $\mathrm{O}_{2}$ that physically exchanges with atmospheric $\mathrm{O}_{2}$. Creeping bentgrass grown with no other environmental stresses can survive in soils with ODR levels as low as $5.0 \times 10^{-8}$ $\mathrm{g} \cdot \mathrm{cm}^{-2} / \mathrm{min}$, whereas most plants require an $\mathrm{O}_{2}$ delivery of $1.5 \times 10^{-7}$ to $2.0 \times 10^{-7} \mathrm{~g} \cdot \mathrm{cm}^{-2} /$ min (Williamson, 1968). During summer months, root $\mathrm{O}_{2}$ requirements increase with high temperatures stimulating root and microbial respiration (Waddington and Baker, 1964; Williamson, 1964). Huang et al. (1998) noted that at high temperatures $\left(35\right.$ to $25^{\circ} \mathrm{C}$ ), creeping bentgrass root viability and root dry matter were reduced when ODR levels were only $2.0 \times 10^{-7} \mathrm{~g} \cdot \mathrm{cm}^{-2} / \mathrm{min}$. The relationship between turf quality and ODR, however, has not yet been defined over a wide range of environmental conditions.

Carbon dioxide is found at very low levels in atmospheric air $(\approx 0.03 \%)$. However, soil $\mathrm{CO}_{2}$ can be 10-100 times greater than atmospheric $\mathrm{CO}_{2}$ (Hillel, 1980; Bremner and Blackmer, 1982). Roots and microbes produce $\mathrm{CO}_{2}$ with the uptake of carbon $(\mathrm{C})$ and $\mathrm{O}_{2}$ during respiration. Increased soil microbial activity occurs with increased temperature, often elevating $\mathrm{CO}_{2}$ concentrations during warmer weather. In poorly aerated soils, $\mathrm{CO}_{2}$ can potentially elevate to toxic levels (Williamson, 1968). Well-aerated soils generally have less potential to accumulate high $\mathrm{CO}_{2}$ concentrations, since atmospheric $\mathrm{O}_{2}$ readily diffuses into the soil, displacing $\mathrm{CO}_{2}$.

The toxicity of $\mathrm{CO}_{2}$ is not fully understood. The most widely accepted hypothesis is high $\mathrm{CO}_{2}$ levels decrease the cytoplasmic $\mathrm{pH}$ of root cells, thereby interfering with water and nutrient uptake and stunting root growth (Chang and Loomis, 1945; Williamson, 1964). Distilled water saturated with $\mathrm{CO}_{2}$ has a $\mathrm{pH}$ $\approx 4.0$ due to the formation of carbonic acid $\left(\mathrm{H}_{2} \mathrm{CO}_{3}\right)$ (Chang and Loomis, 1945). Although no work has been performed on creeping bentgrass and elevated $\mathrm{CO}_{2}$, previous research shows soil $\mathrm{CO}_{2}>6 \%$ to be toxic to growth of broad bean (Williamson, 1968).

Minimal research has been performed on the variable soil concentrations of $\mathrm{O}_{2}$ and $\mathrm{CO}_{2}$ on $\mathrm{C}_{3}$ plants, such as creeping bentgrass. The objective of this study was to determine the effects of elevated soil $\mathrm{CO}_{2}$ on the root growth and turf quality of creeping bentgrass.

\section{Materials and Methods}

Growth cells were constructed to simulate a standard layered golf green (Fig. 1). Polyvinyl chloride (PVC) pipe $(25 \mathrm{~cm}$ in diameter) was cut to $40 \mathrm{~cm}$ in length and the base was fitted with a $25-\mathrm{cm}$-diameter PVC cap. Drainage holes were cut in the center of each cap and covered on the inside of the cap with expanded metal appropriately sized to prevent gravel from clogging the drain hole. Drain holes were fitted with a $2-\mathrm{cm}$ female adapter on the outside of the cap and connected to 2-cm PVC pipe. Individual drains of three growth cells were connected with 4-cm-diameter PVC pipe. On one end of the $4-\mathrm{cm}$ pipe was a p-trap allowing water to drain but did not allow air to pass. On the other end of the pipe a solenoid valve regulated the timing and frequency of gas entry. To prevent water and air leakage, silicon seals were used in all fittings. Aluminum frames were used to support growth cells. 
TuRf MANAgEMENT

Table 1. Particle size distribution percentages of sand used in growth cells compared with USGA recommendations for golf greens.

\begin{tabular}{|c|c|c|c|c|c|c|c|c|c|}
\hline \multirow[b]{2}{*}{ Sample } & \multicolumn{3}{|c|}{ Soil separation $(\%)$} & \multicolumn{6}{|c|}{ Sieve size/sand fraction sand particle diameter (\% retained) } \\
\hline & Sand & Silt & Clay & $\begin{array}{c}\text { Gravel } \\
2 \mathrm{~mm}\end{array}$ & $\begin{array}{c}\text { Very coarse } \\
1 \mathrm{~mm}\end{array}$ & $\begin{array}{l}\text { Coarse } \\
0.5 \mathrm{~mm}\end{array}$ & $\begin{array}{l}\text { Medium } \\
0.25 \mathrm{~mm}\end{array}$ & $\begin{array}{c}\text { Fine } \\
0.15 \mathrm{~mm}\end{array}$ & $\begin{array}{l}\text { Very fine } \\
0.05 \mathrm{~mm}\end{array}$ \\
\hline Clemson Mix & 98.0 & 1.0 & 1.0 & 0.1 & 3.2 & 27.9 & 51.7 & 12.0 & 3.1 \\
\hline USGA Value & $\geq 92$ & $\leq 3$ & $\leq 3$ & & $\begin{array}{l}\text { avel } \\
\text { mbined }\end{array}$ & & & 20 & $\leq 5$ \\
\hline
\end{tabular}

Soil profile construction followed U.S. Golf Association (USGA) recommendations (USGA, 1993) (Table 1). Pea gravel $(10 \mathrm{~cm})$ covered the exit drain, topped by $30 \mathrm{~cm}$ of a mix of 85 sand: 15 peat (v/v) filled each cell. The particle size distribution of the sand met USGA recommendations and was uniformly compacted with a bulk density of $1.41 \mathrm{~g} \cdot \mathrm{cm}^{-3}$.

On 21 Jan. 1999, cells for both experimental runs were seeded with $5.9 \mathrm{~g} \cdot \mathrm{m}^{-2}$ 'Crenshaw' creeping bentgrass and rolled with a PVC pipe to create good seed to soil contact for consistent germination. Grass establishment involved watering of $0.5 \mathrm{~cm} \cdot \mathrm{d}^{-1}$ split evenly between $0800 \mathrm{HR}, 1200 \mathrm{HR}$, and $1500 \mathrm{HR}$. First signs of germination were $4 \mathrm{~d}$ after seeding and grass was cut by hand with scissors at a height of $1 \mathrm{~cm}$ for $14 \mathrm{~d}$. Two weeks following germination, routine fertilization, mowing, and watering practices were initiated. Mowing was performed five times weekly with a motorized hand held trimmer at a height of $0.6 \mathrm{~cm}$ and cells fertilized biweekly with $12 \mathrm{~N}-1.8 \mathrm{P}-6.6 \mathrm{~K}$ liquid fertilizer (Green Relief, Jacksonville, Fla.) N at $1 \mathrm{~g} \cdot \mathrm{m}^{-2}, \mathrm{P}$ at $0.4 \mathrm{~g} \cdot \mathrm{m}^{-2}$, and $\mathrm{K}$ at $0.8 \mathrm{~g} \cdot \mathrm{m}^{-2}$. Growth cells received two daily applications of water (1000 HR and $1500 \mathrm{HR}$ ) equaling 0.5 $\mathrm{cm} \cdot \mathrm{d}^{-1}$ to avoid wilting point. Fungicides were applied as needed for disease control. Azoxystrobin [methyl (E)-2-\{2-[6-(ecyanophenoxy) pyrimidin-4-yloxy]phenyl 3-methoxyacrylate] (Heritage; Zeneca Ag Products, Wilmington, Del.) and chlorothalonil (tretachloroisophthalonitrile) (Daconil Ultrex, Zeneca Ag Products, Wilmington, Del.) were applied ai at 0.1 and $0.93 \mathrm{~g} \cdot \mathrm{m}^{-2}$, respectively. Box fans were installed to stimulate air movement in turf canopy to decrease humidity and heat stress.

Treatments consisted of varying levels of $\mathrm{CO}_{2}: \mathrm{O}_{2}$. Carbon dioxide levels were inversely linear to $\mathrm{O}_{2}$. Treatments included an untreated check (no air injection), 2.5\%, 5.0\%, and $10.0 \% \mathrm{CO}_{2}$ mixed with $17.5 \%, 15.0 \%$, and $10.0 \% \mathrm{O}_{2}$, respectively, along with standard $80 \% \mathrm{~N}_{2}$. Gas mixtures were injected into the drainlines opposite the side of the p-trap to force the mixtures upward into the growth cells. The connecting drainlines delivered the gas to three growth cells representing the experimental positions. In order to maintain desired levels of $\mathrm{CO}_{2}$, gases were injected for 1 min every $2 \mathrm{~h}$ to growth cells at a flow rate of $5500 \mathrm{~cm}^{3} \cdot \mathrm{min}^{-1}$. An electric solenoid valve regulated gas entry. Preliminary work included monitoring soil gas concentrations $\left(\mathrm{O}_{2}\right.$ and $\left.\mathrm{CO}_{2}\right)$ after purging to determine the rate and frequency of gas entry. Untreated growth cells maintained a $\mathrm{CO}_{2}$ concentration of $<1 \%$. Gas levels $\left(\mathrm{O}_{2}\right.$ and $\left.\mathrm{CO}_{2}\right)$ were monitored with a portable infra-red gas analyzer (model \#1810-2772; Soil Scientific, Deep River, Conn.) daily from growth cells for assurance of soil atmosphere levels consistent with injected concentrations. Gas levels were consistently maintained within $0.5 \%$ of injected concentration. Treatments were imposed for $20 \mathrm{~d}$ during runs 1 and 2 on 20 - and 26-week-old bentgrass, respectively. Separate runs occurred 11 June to 30 June 1999 and 24 July to 12 Aug. 1999. Runs were performed on different growth cells. Maximum ambient temperatures were maintained between 35 to $40{ }^{\circ} \mathrm{C}$ to provide a stressful environment for creeping bentgrass. Minimum nighttime temperatures ranged between 17 to $20{ }^{\circ} \mathrm{C}$.

Visual ratings of turf quality, comprised of color, health, density, and uniformity, were determined every $4 \mathrm{~d}$. Turf quality was rated on a 1-9 scale with $9=$ best turf quality. Turf quality was considered unacceptable when <7. After completion of each experimental run, a 5-cm-diameter $\times 30$-cm-deep soil core was extracted. Root depth $(\mathrm{cm})$ was measure by averaging the two deepest roots within each soil core prior to washing. Root mass was measured after washing sand and organic matter from the roots with an automated air and water pressurized root washer (Smucker et al., 1982). Samples were dried at $80{ }^{\circ} \mathrm{C}$ for $3 \mathrm{~d}$ and weighed (g).

The study was a randomized completeblock design (RCBD) with $\mathrm{CO}_{2}$ level and experimental position representing the two factors investigated. Experimental position refers to growth cell location within $\mathrm{CO}_{2}$ level. In the study, three experimental posi-

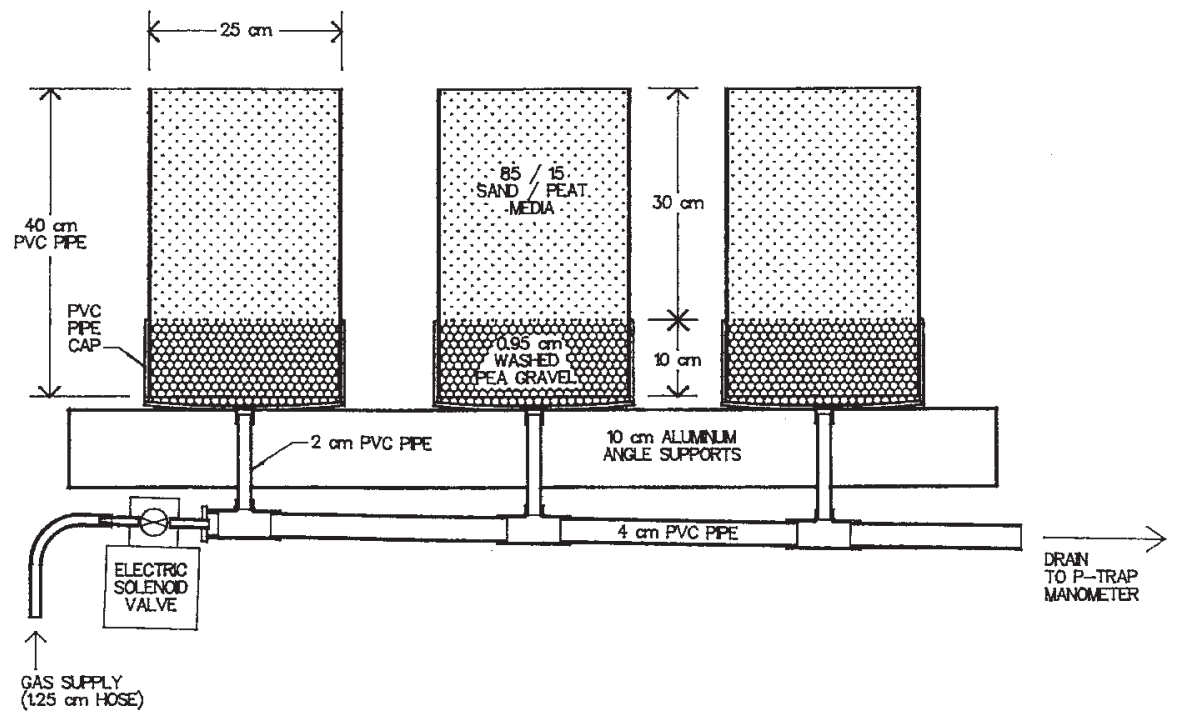

Fig. 1. Cross section of growth cells showing gas injection piping and experimental position representing sequence of growth cell from gas injection point. tions were established with position 1 being closest to gas entry point (Fig. 1). Two runs were performed representing the two replications, which were the blocks. Root data and turf quality data were analyzed using analysis of variance (ANOVA) general linear model procedure (GLM) (SAS Institute, Cary, N.C.). Treatment $\left(\mathrm{CO}_{2}\right)$ and experimental position main effects and the treatment by experimental position interaction were tested. Means separations were performed on significant factors using LSD. An $\alpha=0.05$ was used for turf quality interpretations. Due to inherent variability in similar root studies, an $\alpha=0.10$ was used for root data testing (Wiecko et al., 1993).

\section{Results and Discussions}

Results of ANOVA of root data showed a significant treatment effect with root mass $(P=0.0293)$ and root depth $(P=0.0210)$, but no significant experimental position or treatment by experimental position effects. Root mass and depth were reduced with elevated levels of soil $\mathrm{CO}_{2}$. A $40 \%$ [percentage calculated as: (treated-untreated)/untreated)] decrease in root mass occurred with soil $\mathrm{CO}_{2}$ levels $\geq 2.5 \%$ (Fig. 2). A $10 \%$ decrease in root depth also resulted from $\mathrm{CO}_{2}$ levels $\geq 2.5 \%$ (Fig. 3). Creeping bentgrass exposure to elevated concentrations of $2.5 \%, 5 \%$, and $10 \%$ soil $\mathrm{CO}_{2}$ for $20 \mathrm{~d}$ reduced root mass and depth. Additional research should investigate long-term elevated soil $\mathrm{CO}_{2}$ exposure of creeping bentgrass putting greens

Results of ANOVA of turf quality data showed a significant treatmenteffect $(P<0.003)$ 


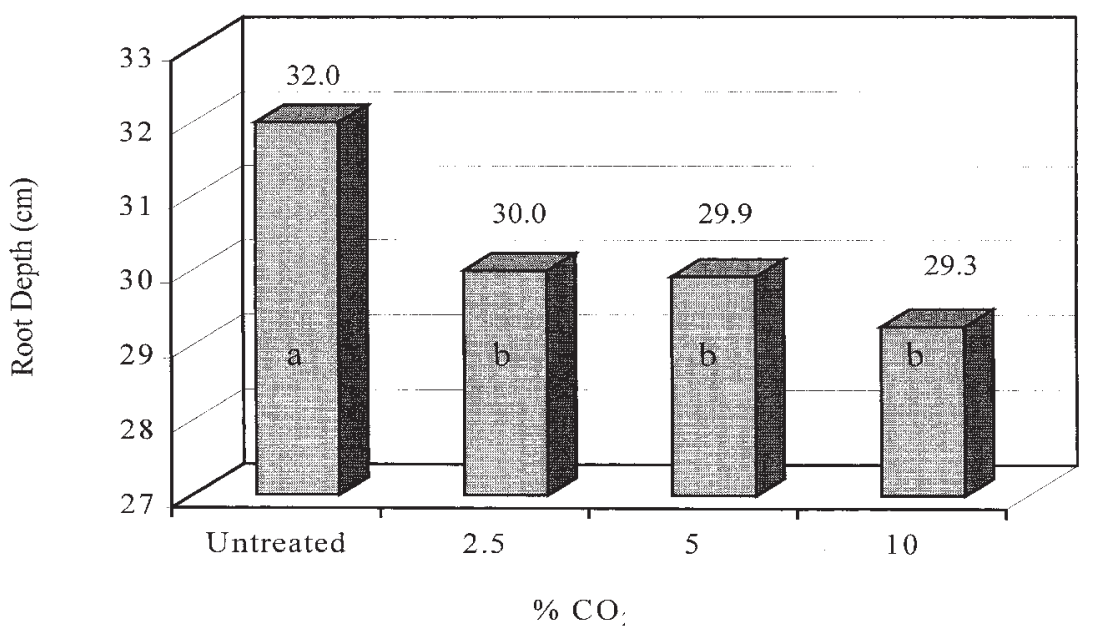

Fig. 2. Root mass of creeping bentgrass $20 \mathrm{~d}$ following initiation of elevated soil $\mathrm{CO}_{2}$. Within each $\mathrm{CO}_{2}$ level, means followed by day after gas treatment, means followed by the same letter are not significantly different according to Fischer's protected LSD at $\alpha=0.10$.

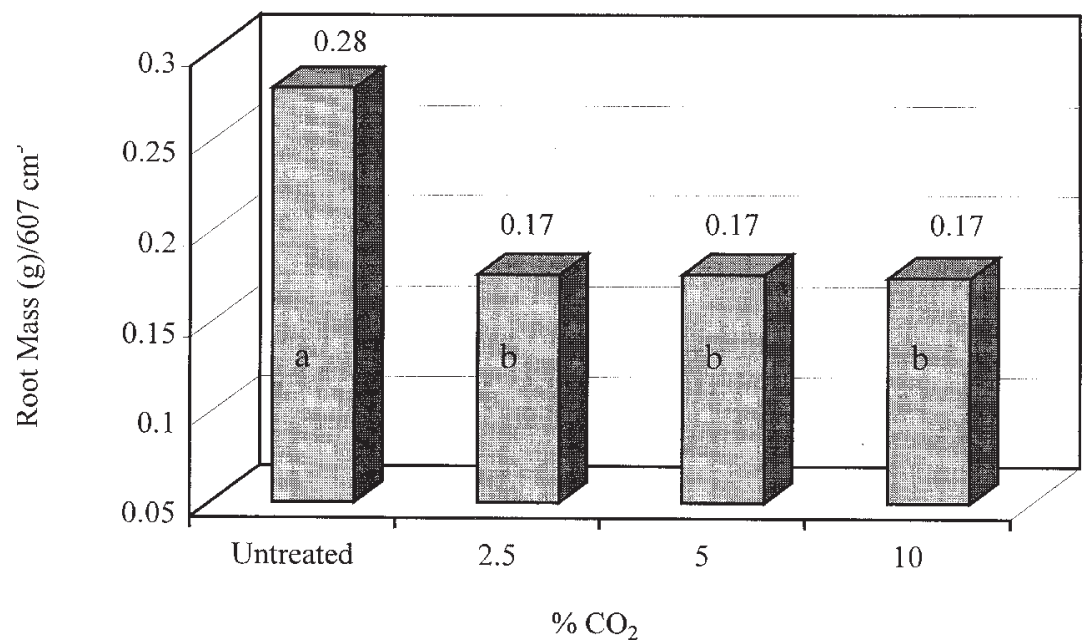

Fig. 3. Root depth of creeping bentgrass $20 \mathrm{~d}$ following initiation of elevated soil $\mathrm{CO}_{2}$. Within each $\mathrm{CO}_{2}$ level, means followed by the same letter are not significantly different according to Fischer's protected LSD at $\alpha=0.10$.

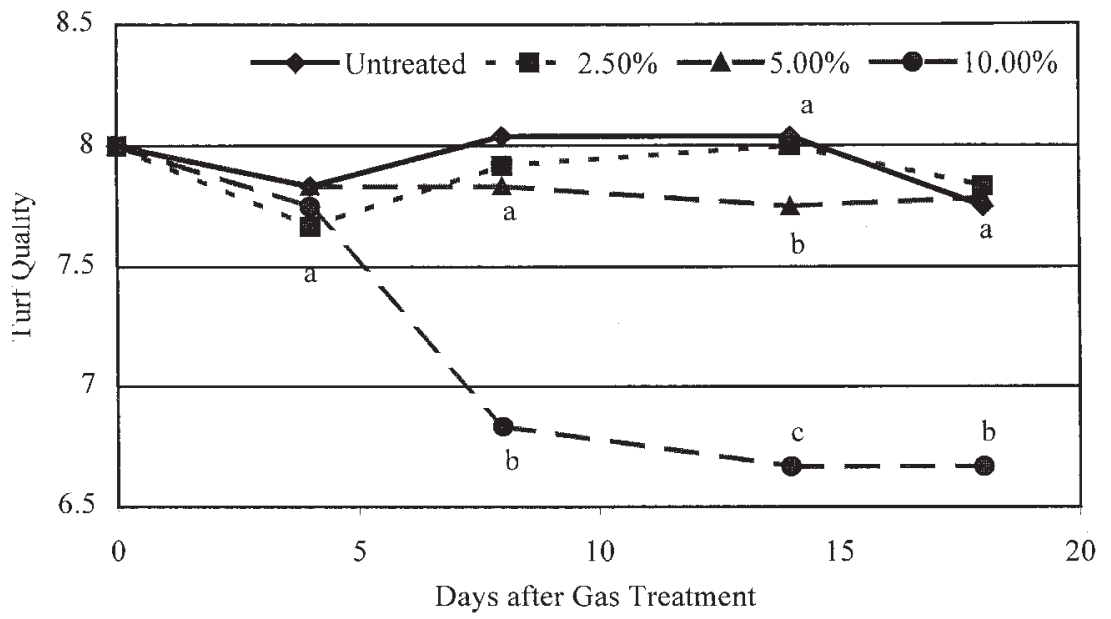

Fig. 4. Visual rating of creeping bentgrass turf quality with various levels of elevated soil $\mathrm{CO}_{2}$. Within each $\mathrm{CO}_{2}$ level, means followed by the same letter are not significantly different according to Fischer's protected LSD at $\alpha=0.05$. for all rating periods except 4 days after initiation, but no significant experimental position or treatment by experimental position effects. Turf quality was reduced by elevated concentrations of soil $\mathrm{CO}_{2}$. After 1 week of $10 \% \mathrm{CO}_{2}$, turf quality was unacceptable (Fig. 4). Turf quality was reduced to $<7.0$ with $10 \% \mathrm{CO}_{2}$ from day 8 to 18 . The $5 \% \mathrm{CO}_{2}$ concentration reduced turf quality from the untreated however it still maintained acceptance. Carbon dioxide levels of $2.5 \%$ did not affect turf quality. Decreased turf quality with $5 \%$ and $10 \%$ soil $\mathrm{CO}_{2}$ may have resulted from toxic levels of $\mathrm{CO}_{2}$. No decrease in turf quality occurred with the $2.5 \% \mathrm{CO}_{2}$ concentration, however a decrease in root mass and depth did occur. Higher $\mathrm{O}_{2}$ concentration associated with the $2.5 \% \mathrm{CO}_{2}$ possibly provided adequate soil oxygenation for root respiration, improving turf quality. Additional physiological stress, such as temperature, may have attributed to lower $\mathrm{CO}_{2}$ levels damaging creeping bentgrass.

\section{Conclusions}

High temperatures and soil moisture levels generally increase potential for high $\mathrm{CO}_{2}$ concentrations and limited $\mathrm{O}_{2}$ in golf course putting greens. This research demonstrated elevated levels of soil $\mathrm{CO}_{2}$ are detrimental to creeping bentgrass root growth and turf quality. Decreased root mass and length followed $20 \mathrm{~d}$ of soil $\mathrm{CO}_{2}$ equaling or exceeding $2.5 \%$. Unacceptable turf quality was found with $10 \%$ soil $\mathrm{CO}_{2}$. Similar inflated levels in a golf course green may potentially cause greater bentgrass damage due to increased stress incurred from other physical and biological stresses associated with golf course management. Further research will investigate elevated soil $\mathrm{CO}_{2}$ effects at various temperatures and soil moisture regimes. Current and additional research will determine the concentration of soil $\mathrm{CO}_{2}$ that is toxic on the growth and performance of creeping bentgrass putting greens.

\section{Literature Cited}

Beard, J.B. 1997. Dealing with heat stress on golf course turf. Golf Course Mgt. 7:54-59.

Brady, N.C. 1984. The nature and properties of soils. Macmillan, New York.

Bremner, J.M., and A.M. Blackmer. 1982. Composition of soil atmospheres, p. 873-901. In A. Klute and A.L. Page (ed.). Agronomy monograph. no. 9 ( $2^{\text {nd }}$ ed.). Methods of soil analysis, part 2. Chemical and microbiological properties. Amer. Soc. of Agron., Madison, Wisc.

Chang, H.T., and W.E. Loomis. 1945. Effect of carbon dioxide on absorption of water and nutrients by roots. Plant Physiol. 20:221-232.

Christians, N.E. 1998. Fundamentals of turfgrass management. Sleeping Bear Press., Chelsea, Mich.

Hillel, D. 1980. Fundamentals of soil physics. Academic, San Diego.

Huang, B., X. Liu, and J.D. Fry 1998. Shoot physiological responses of two bentgrass cultivars to high temperature and poor soil aeration. Crop Sci. 38:1219-1224.

Letey, J., O.R. Lunt, L.H. Stolzy, and T.E. Szuskiewicz. 1961. Plant growth, water use and nutritional response to rhizosphere differ- 
entials of oxygen concentrations. Soil Sci. Soc Amer. Proc. 25:183-186.

SAS Institute. 1987. SAS/STAT guide for personal computers. Version 6 ed. SAS Institute Cary, N.C.

Smucker, A.J.M., S.L. McBurney, and A.K. Srivastava. 1982. Quantitative separation of roots from compacted soil profiles by the hydropneumatic elutriation system. Agron. J. 74:500-503.
United States Golf Association Green Section Staff. 1993. USGA recommendations for a method of putting green construction. The 1993 Revision. USGA Green Section Record. 31(2):1-3.

Waddington, D.V., and J.H. Baker. 1964. Influence of soil aeration on the growth and chemical composition of three grass species. Agron. J. 57:253-258.

Wiecko, G., R.N. Carrow, and K.J. Karnok. 1993. Turfgrass cultivation methods: Influence on soil physical, root/shoot, and water relationships, p. 451-457. In: R.N. Carrow, N.E. Christians, and R.C. Shearman (eds.). Intl. Turfgrass Soc. Res. J. 7. Overland Park, Kans.

Williamson, R.E. 1964. The effect of root aeration on plant growth. Soil Sci. Soc. of Amer. Proc. 28:86-90.

Williamson, R.E. 1968. Influence of gas mixtures on cell division and root elongation of broad bean. Agron. J. 60:317-321. 